\title{
Ssciendo
}

Ethics \& Bioethics (in Central Europe), 2019, 9 (3-4), 98-105

DOI:10.2478/ebce-2019-0014

\section{Ethical teachings of Classical Antiquity philosophers in the poetry of Saint Gregory of Nazianzus}

\author{
Erika Brodňanská ${ }^{1}$ \& Adriána Koželová ${ }^{2}$
}

\begin{abstract}
The paper focuses on the ethical teachings of Classical Antiquity philosophers in the poetry of Saint Gregory of Nazianzus, especially on the parallels between the author's work and the Cynics and the Stoics. The syncretic nature of Gregory's work, reflected in the assimilation of the teachings of ancient philosophical schools and the then expanding Christianity creates conditions for the explanation and highlighting of basic human virtues. Gregory of Nazianzus' legacy also draws on the teachings of such philosophers as Plato and Aristotle, but he always approaches them from the perspective of a strictly Christian worldview. He understands philosophy as a moral underlying basis from which one can draw inspiration for a virtuous and happy life. Gregory thinks that philosophy cannot harm Christians in the pursuit of a virtuous life. Nevertheless, Christian teachings and God are the highest authority. They stand above all philosophical schools or ideas advanced by specific philosophers. Gregory's moral poetry thus directs his readers, if they are to deserve eternal life, to follow the commandments, which is possible only if one lives a practical and virtuous life.
\end{abstract}

Keywords: Gregory of Nazianzus, moral poetry, Cynicism, Stoicism, virtues

The Golden Age of Patristic Literature, as the $4^{\text {th }}$ and $5^{\text {th }}$ century CE are often referred to, provides an abundance of material of great theological and literary significance. It is a period in which the declining culture of pagan antiquity meets the successfully expanding Christianity. The two cultural paradigms are also confronted in the works of St. Gregory of Nazianzus - a theologian and one of the most important church fathers of the Eastern Christian tradition, who also excelled as rhetorician and poet. He taught and explained basic questions of faith, provided reading of the Scripture, expressed his opinions on education, preached and praised, contemplated on being, offered insight into his innermost thoughts, pondered moral dilemmas, and, in doing so, he did not hesitate to draw on the ancient pagan philosophers, selecting worthy ideas and offering them to young Christians. Ultimately, each ancient philosophical system comprises ethical teachings or criticism of morality, calls for a certain way of behaving and entails life choices.

Moral education was highly regarded by the ancient Greeks. This is evidenced by the statements of the seven sages ${ }^{3}$ gathered in Delphi in order to sacrifice the fruit of their wisdom to Apollo in his temple. The sages' votive offerings were the inscriptions of words recognized today by the whole world (e.g. Know yourself, Not too much of anything). ${ }^{4}$ The inventory of these and other maxims and adages was engraved in stone near the temple. The habit of displaying similar inscriptions in public places, so that passers-by could always see them, spread throughout the Greek world (Hadot, 2004, p. 21). The tradition of educating the youth

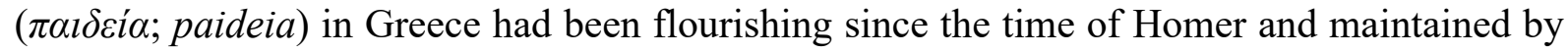
those who had the so-called $\dot{\alpha} \rho \varepsilon \tau \dot{\eta}$ (arete), an ability inherited by virtue of noble lineage, since it pertained to members of the aristocracy. The word $\dot{\alpha} \rho \varepsilon \tau \dot{\eta}$ denotes something that is appreciated, conspicuous and inspiring awe. In Homer's times it was prowess in battle and physical perfection. Nevertheless, the Greeks had gradually shifted from admiring military

\footnotetext{
${ }^{1}$ University of Prešov, Faculty of Arts, Institute of Romance Studies, Prešov (Slovakia); erika.brodnanska@unipo.sk

${ }^{2}$ University of Prešov, Faculty of Arts, Institute of Romance Studies, Prešov (Slovakia); adriana.kozelova@unipo.sk

${ }^{3}$ Thales of Miletus, Pittacus of Mitylene, Solon of Athens, Chilon of Sparta, Periander of Corinth, Bias of Priene Kleobulos z Lindu, Cleobulus of Lindos.

${ }^{4}$ Cf. Plato, Protagoras 343A and Plutarch, De E 385f.
} 
valor to praising mental capabilities. Thus, the meaning of $\dot{\alpha} \rho \varepsilon \tau \dot{\eta}$ shifted from the physical domain to the domain of the soul that excels in knowledge, goodness and morality. For the philosophers, $\dot{\alpha} \rho \varepsilon \tau \eta \dot{~ b e c a m e ~ v i r t u e ~ a n d ~ n o b i l i t y ~ o f ~ t h e ~ s o u l ~(H a d o t, ~ 2004, ~ p . ~ 11) . ~}$

The subject has been explicitly treated by St. Gregory of Nazianzus in two of his moral poems. Poems I,II, $26^{5}$ and I,II, $27^{6}$ have identical names, In nobilem male moratum, implying, that they are addressed to someone of noble descent, but lacking morals. Poem I,II,26 starts with a reference to an exceptional man, ${ }^{7}$ who, despite being of low origin, countered ridicule

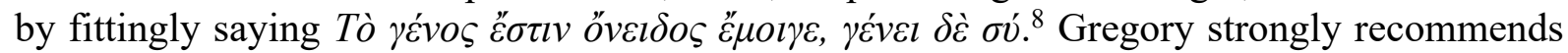
that the addressee of the poem behave in the same way and not approve of anything but virtuous behavior. ${ }^{9}$ According to Gregory, the evildoers, those who do not practice $\dot{\alpha} \rho \varepsilon \tau \dot{\eta}$ and do not ennoble their soul are slaves. On the contrary, he calls the free aristos (the best). ${ }^{10}$ At the end of the poem the author states that it is better to be the best offspring of vile lineage than to be the worst of a noble one. For a rose also grows out of a thorny bush. And yet, it is a rose. Though, if in good soil a bramble sprouts it fits only to be put on the fire. ${ }^{11}$ And he develops this further: If you are vile and yet boast of noble ancestry, you are but a donkey with the pride of a horse. ${ }^{12}$ The donkey and the horse also appear in the poem I,II,27. Nevertheless, compared to the previous poem, the latter is more emphatic and articulate in the treatment of the nobleness

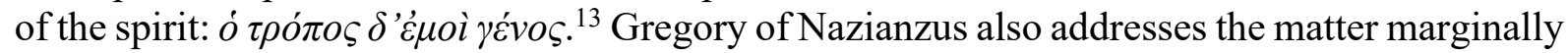
in other poems. Of these, let us mention the one that precedes the above mentioned poems in the collection Patrologia Graeca ${ }^{14}$ (PG) and deals primarily with anger (I,II,25 Adversus iram). In it, Gregory identifies the nobility (origin) as a child's toy, ${ }^{15}$ clearly debasing those who capitalize on the merits of others and implying the worthiness of virtue.

The roots of the teachings on ethics can be found in works by many ancient philosophers. Plato considered the cardinal virtues of temperance, wisdom, courage and justice ${ }^{16}$ as prerequisites for the success of civil society (Plato, The Republic 427d-434c). The most important objective in Plato's Academy was to learn and adopt a philosophical way of life. Such life then ensures the happiness and salvation of the soul (Brisson, 1993, p. 480). To live a philosophical life means to adhere to an intellectual and spiritual life, to accomplish a "conversion" in which the "whole soul" and all moral life are at stake (Hadot, 2004, p. 65). However, it was Aristotle's school that offered training in an exclusively philosophical way of life. ${ }^{17}$ Aristotle viewed virtue as the improvement of human nature itself - i.e. reason (Störig, 1985, p. 185). According to Aristotle, it is in reason that one can find the primary type of

\footnotetext{
${ }^{5}$ PG 37, 851-854.

${ }^{6}$ PG 37, 854-856.

${ }^{7}$ Although Gregory does not specify who the exceptional man was, we know that he reacted similarly to Cicero, when he was advised to change his name (Cicero = Chickpeas) in the senate when he entered political life (Plutarch, Cicero 1).

${ }^{8}$ My family is my shame, but you are the shame of your family (I,II,26,4b-5a; PG 37, 851).

${ }^{9}$ I,II,26,5-6 (PG 37, 851).

${ }^{10} \mathrm{I}, \mathrm{II}, 26,29$ (PG 37, 853).

${ }^{11}$ I,II, 26,36-38 (PG 37, 853-854).

${ }^{12}$ I,II,26,39-40 (PG 37, 854).

${ }^{13}$ Ethics/morality is my family (the way of life) (I,II,27,10; PG 37, 854).

${ }^{14}$ Patrologiae cursus completus. Series Graeca (1857-1858). Accurante J. P. Migne. Paris.

${ }^{15}$ I,II,25,448 (PG 37, 844).

${ }^{16}$ According to Plato, temperance is the ability to find a true balance between enjoyment and ascetic life, wisdom is the domain of reason and courage comes from the will. Justice is the balance of the three abilities mentioned above.

${ }_{17}$ Although conducting mathematical research and practicing philosophical discussions, Plato's school had a political agenda.
} 
happiness, ${ }^{18}$ philosophical happiness, which is associated with $\theta \varepsilon \omega \rho i \alpha($ theoria $),{ }^{19}$ i.e. the way of life that is devoted solely to intellectual activity (Hadot, 2004, p. 80). The Greek $\theta \varepsilon \omega \rho i \alpha$ means observation, exploration, knowledge (Panczová, 2012, p. 616). The Greeks sought wisdom, that is, knowledge that originates in the perception of what is seen. Since people mostly want to see only what they like, for the Greeks, the purpose of $\theta \varepsilon \omega \rho i \alpha$ was also a happy life (Špidlík, 2010, pp. 13, 24).

The topic of philosophical happiness was also developed in the writings of St. Gregory of Nazianzus, who approached it from the vantage point of disease. ${ }^{20}$ The issue is addressed explicitly in three short moral poems (I,II,35 ${ }^{21}$ De philosophica paupertate; I,II,36 $6^{22}$ De eodem argumento; I,II, $39^{23}$ De fortuna et providentia). In the first two, Gregory uses the image of disease. Its purpose is to create and confirm the stereotypes of restraint but also of justice (and in so doing, further reinforce their overall significance in his writings). These fixed patterns and perception of reality stem from the very nature of Gregory's work. His moral poetry targets and shapes the recipients. The author clearly declares his attitudes and urges the reader to follow his example. This creates space for internal projection, which makes the reader understand disease through comparative reflection. Gregory urges the doubtful to see the virtues in such perspective that they understand that bliss and earthly pleasures lead to downfall. In the third poem $^{24}$ the author no longer needs the archetypal paradigms - abundance and misery pertaining to disease, which may affect the rich and the poor alike. Yet, the rich lose seemingly more, since they do not fear only the loss of health or even life, but also the loss of wealth. In the poem, Gregory divides people into two categories: those who are blissful, happy and enjoy all things profane, and those who are moderate and guided by reason. The final verse of the poem "An abyss of bliss is not worth as much as a drop of reason" 25 reminds the reader of the morality of fables, which is accentuated by the image of the abyss. Although of colossal proportions, it ultimately is of lesser significance than a drop of reason. The same image advances the idea of void, in which bliss becomes misfortune for those who fall for it.

Relegating the notion of $\theta \varepsilon \omega \rho i \alpha$ exclusively to the domain of what is perceptible by reason corresponds to Platonic tradition and was later confirmed by Aristotle. However, this position had been discredited by the Stoics. The Stoics despised philosophers who did not reflect the acquired knowledge in their behavior (Špidlík, 2010, p. 186). Likewise, Gregory of Nazianzus, in the poem I,II,33 Tetrastichae sententiae, asks in the very first verse: Do you prefer practice or theory? ${ }^{26}$ J. Lemaître, as cited by T. Špidlík, states that Gregory is still a Christian of classical

\footnotetext{
${ }^{18}$ Cf. Aristotle, Nicomachean Ethics X, 1178-1179. Aristotle distinguished between two types of happiness. First, happiness one finds in an active life, in politics, and that is achieved by leading a virtuous life; and, a second type called philosophical happiness.

${ }^{19}$ As far as Christians are concerned, the apostolic fathers did not even have this word in their vocabulary. It appeared only with Clement of Alexandria and Origen in the $2^{\text {nd }}$ century CE. It was appropriated by St. Gregory of Nazianzus as the basis of the Greek understanding of knowledge, and it became the basis for his own approach to knowledge (Špidlík, 2010, pp. 31, 33).

${ }^{20}$ I,II,35: Hedonist, when you are ill, do you enjoy the riches? If you are tormented by illness, know that you have got the cure too. On the other hand, there are those who are poor and modest. They are neither tormented nor in need of the cure. But know that in such a case I would prefer he who is rich and weak and confused to he who is poor, healthy and already wise.

I,II,36: Imagine somebody getting ill and in need of medication and who wants to get rid of the hardship. Imagine someone else, who is healthy and does not need anything. Who will you say is happy? Everybody says it is he who is healthy. He might live in great poverty, but is happier still than he who possesses gold and is sick.

${ }^{21}$ PG 37, 965.

${ }^{22}$ PG 37, 965.

${ }^{23}$ PG 37, 967-968.

${ }^{24}$ I,II,39: Once a luxury loving person said: "I would rather have a drop of luck, than a bucket full of brains". And a wise person replied: "A drop of wisdom is worth more than an abyss filled with luck."

${ }^{25}$ I,II,39,4 (PG 37, 968).

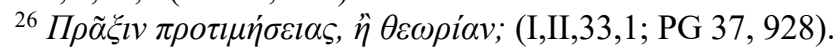


cultural heritage. His notion of $\theta \varepsilon \omega \rho i \alpha$ is marked by the thoughts of Aristotle and the Stoics. He believes the knowledge stemming from $\theta \varepsilon \omega \rho i \alpha$ is reached through reason, but reason then further examines the knowledge, scrutinizes it and explores (Lemaître, 1953, 1814 in Špidlík, 2010, p. 188). Nevertheless, Gregory knows of yet another form of knowledge that he deems real, spiritual. It arises from $\pi \rho \tilde{\alpha} \xi l \varsigma$ (praxis), i.e., the way people behave. $\Pi \rho \tilde{\alpha} \xi l \varsigma$ was for Gregory the sum of all virtues (Špidlik, 2010, pp. 189, 197). This view is supported by the verses of his poem I,II,33, where he states that salvation rests more with deeds without words than with words without deeds, ${ }^{27}$ and that grace is not given to those who speak, but to those who do good. ${ }^{28}$

Revisiting the teachings on virtues in individual philosophical schools, the above-mentioned Stoics saw virtue in the ability to recognize good from evil, that is, in a kind of inner moral strength (Störig, 1985, p. 195). It is the teachings of the Stoics that are reflected in Gregory's poem I,II,25 Adversus iram. The poem is all the more interesting, since it lets the reader contemplate Gregory's own feelings. In the poem's prologue, the author expresses anger over his own anger, ${ }^{29}$ and the fact that he cannot prevail over it. ${ }^{30}$ Gregory fights against anger inside him as well as against the anger he feels towards his enemies. He intends to defeat anger by redirecting it from the outer world against himself. The approach he takes is to stay silent, to adopt a strategy of deeds without words. And although, like the Stoics, Gregory yearns for the complete elimination of passions, he is content to at least tame them. He welcomes any progress in the fight against these as he calls them, ailments or diseases. Although, he is aware that $\dot{\alpha} \pi \dot{\alpha} \theta \varepsilon l \alpha$ (apatheia; state without passion), the supreme goal of human askesis, is attainable only with the help of God. ${ }^{31}$

After the introductory remarks, Gregory delves deeper into questions on anger: where it comes from and how to fight it. In defining anger, he relies on the writings of the men of long ago, ${ }^{32}$ philosophers who devoted their time to seeking the origin and nature of things, in this case, passions. Gregory, in his approach, uses three definitions. First, physiological (vv. 35$38),{ }^{33}$ for which anger ( $\varepsilon \kappa \sigma \tau \alpha \sigma l \varsigma$; ekstasis) is the boiling up of blood in the heart. ${ }^{34}$ Second, psychological (vv. 39-42), ${ }^{35}$ which understands anger as an effort to retaliate, distinguishing

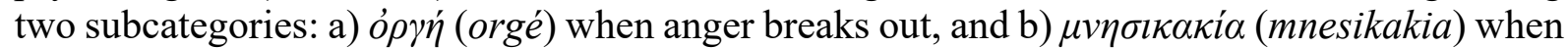
it remains in the soul and waits for appropriate opportunities. ${ }^{36}$ Finally, the third, combined (vv. 43-45), ${ }^{37}$ in which the willingness to retaliate causes the physiological phenomenon. ${ }^{38}$ Gregory concludes the topic and does not deem it worth further reflection. Nevertheless, he further underlines the importance of reason. Verses $47-53^{39}$ read: For they all undoubtedly know that reason rules everything. It is an ally in the fight against passions given to people by

\footnotetext{
${ }^{27}$ I,II,33,21 (PG 37, 929).

${ }^{28}$ I,II,33,24 (PG 37, 930).

${ }^{29}$ The poem was written following Gregory's experience in Constantinople in 381 (Oberhaus, 1991, p. 2), when he was the bishop there and for some time he also chaired the then held council. He was bishop there for only about six weeks, when he abdicated as bishop and chairman. Nonetheless, he was deeply wounded and disappointed that 150 bishops accepted his resignation without major objections and that the Emperor accepted his departure too (White, 1996 p. XXIII; see also Brodňanská, 2017, p. 33).

${ }^{30}$ For more information on the poem see Oberhaus, 1991, p. 1-10.

${ }^{31}$ I,II, 25,1-30 (PG 37, 813-815).

${ }^{32}$ I,II, 25,33 (PG 37, 815).

${ }^{33} \mathrm{PG} 37,816$.

${ }^{34}$ Cf. Plato, Kratylos 419E.

${ }^{35} \mathrm{PG} 37,816$.

${ }^{36}$ This characteristic is provided by Diogenes Laërtius (VII 113), but also by Cicero (Tusc. disp. IV, 9, 21).

${ }^{37}$ PG 37, 816

${ }^{38}$ The definition of anger as correlation between body and soul was also entertained by Aristotle (De anima 403a16-28).

${ }^{39}$ PG 37, 816-817.
} 
the Lord. Our houses protect us from the hail, bushes from the cliffs, bastions from abysses and walls protect those who have to escape the battle. Likewise, reason protects us from mounting anger. Gregory calls the reason a teacher of good things ${ }^{40}$ and one of the means of helping people face anger.

Gregory of Nazianzus sees another means of combatting anger in the guidance of the soul through speech, ${ }^{41}$ in which speech should enchant the mind with positive examples. Consequently, the author uses examples taken from the Bible, but does not avoid profane sources either, because, as he writes: it is useful to take the fruit of lesser works (i.e. pagan) since they might hide something good and useful. ${ }^{42}$ The figures of the Old Testament - Moses, Samuel, and David -, as well as the ones of the New Testament - the Apostle Peter and the Martyr Stephen depicted as the embodiment of Christ's deeds -, are complemented by the figures of profane world: Aristotle, ${ }^{43}$ Alexander the Great, Pericles, and Constantine II, who, meanwhile, became a Christian emperor.

Gregory does not hesitate to use exorcism in his struggle against anger, in accordance with Socrates, who recommended it as a means of curing anger. It is the poem's epilogue ${ }^{44}$ in which the author refers to this method of protecting himself from the works of the demon, i.e., anger.

In his poetry, Gregory of Nazianzus constantly emphasizes the importance of knowing God. The crucial part of knowing God was, in the Eastern Roman tradition, associated with virtues, namely the practice thereof (Špidlík, 2010, p. 197). Gregory himself indicates in one of his speeches that it is necessary to practise virtues because they adorn the house of the soul (i.e., body) until it is illuminated by the light of knowledge of the divine mysteries, for only similar phenomena apprehend one another $(\mathrm{Or} .39,10)$. In this regard, the poem I,II, $10^{45}$ De virtute offers a more general and comprehensive lesson on virtues. It is addressed to a young man, apparently Gregory's nephew Nicobulo (Crimi, 1995, p. 30). In an extensive introduction (vv. 1-217), Gregory discusses the true role of man, which is to approach God. He specifies all the things he deems superfluous in search of God and he questions the value of the things people cherish. He also ponders the subject of the existence of wisdom among the Greeks and questions how one could call them wise if they do not know of the existence of one God. Consequently, Gregory references the teachings of the ancient philosophical schools pertaining to the moral lessons not only by using allusions, but also by explicitly naming the representatives of the individual philosophical schools. Gregory uses these devices to educate his nephew, even though the philosophers in question were pagan. He further declares that some of these "wise" men can place virtue first. Gregory generally refers to the wise by using a comparison, such as in yet another poem Adversus iram: "But I will mention some of them, so that you learn about virtues. It feels as if I was picking roses from among thorns, when I am learning the best from the non-believers" (I,II,10,214-217). ${ }^{46}$ Pointing to the outstanding men (representatives of the profane world as well as characters from the Bible), Gregory draws the attention of the young

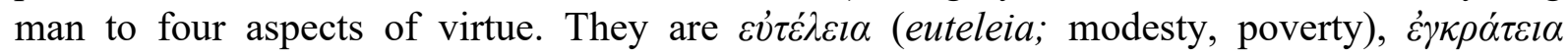
(enkrateia; temperance), $\dot{\alpha} v \delta \rho \varepsilon i \alpha$ (andreia; bravery) a $\sigma \omega \varphi \rho o \sigma v ́ v \eta$ (sofrosyne; morality, prudence).

The first of the virtues Gregory mentions is poverty, highlighting its many faces: modesty, simplicity, selflessness, restraint, and independence from property. Simplicity, understood as satisfaction with the little, was practised by all philosophical schools of Antiquity, especially

\footnotetext{
${ }^{40}$ I,II,37,364 (PG 37, 838).

${ }^{41}$ Cf. Plato, Phaedrus 261A.

${ }^{42}$ I,II, 25,256-257 (PG 37, 831).

${ }^{43}$ In his verses, Gregory speaks about a man from Stageira (birthplace of Aristotle) who has overcome his anger and has not hit a slave. This is probably Gregory's lapsus memoriae because the anecdote pertains to Plato.

${ }^{44}$ I,II, 25,516-546 (PG 37, 848-851).

${ }^{45}$ PG 37, 680-752.

${ }^{46}$ PG 37, 695-696.
} 
by the Cynics. Of these, St. Gregory chose for his nephew the example of Diogenes of Sinope and Crates of Thebes (I,II,10,218-258). ${ }^{47}$ Diogenes used to sleep behind the Athenian city walls in a discarded amphora (the famous barrel), ate what he found, got rid of his property and was said to be wandering with his wife. Gregory further praises the poverty of Cleanthes of Assa (I,II, 10,286), ${ }^{48}$ one of the Old Stoics, who is said to have come to Athens so poor that he had to make money by drawing water and voluntarily died of hunger. The author also admires the unselfishness of Aristid who, despite managing the Athenian treasury, had almost no money at the time of his death and had to be buried at state expense (I,II,10,341-349). ${ }^{49}$ When addressing moderation, Gregory recalls the wise maxim he had heard of the need to practise restraint when eating ${ }^{50}$ (I,II,10,56-587). ${ }^{51} \mathrm{He}$ adds that a fat abdomen does not make a sharp mind. This idea resonates in many of Gregory's poems, but in the above mentioned poem he wants to give explicit examples to Nicobulo and highlights the behavior of the Cynic, Kerkides and the Stoics, since they provide only "modest" bread and water with vinegar (I,II,10,595-611). ${ }^{52}$ Regarding courage, Gregory asks Nicobulo who is the object of his admiration. The young man admires the courage of Leos and his three daughters, who were sacrificed in order to save Athens ${ }^{53}$; for the rescue of Thebes, Menoikeos ${ }^{54}$ scarified himself. He admires how Epictetus and Anaxarchus $^{55}$ could endure pain, but also the fact that Socrates drank poisonous hemlock (I,II,10,676-696) ${ }^{56}$ Finally, Gregory highlights Xenocrates, Epicurus and Polemon, who tried to live virtuously and were able to overcome the seduction of pleasure. He also praises Alexander, who, although having captured Darius' beautiful daughters, did not approach them inconveniently (I,II,10,774-828) ${ }^{57}$ (Brodňanská, 2008, pp. 109-114).

When we examine the examples used by Gregory, we notice that he resorts mainly to the Cynics and Stoics. Cynicism was exclusively an ethical and practical philosophical movement. It understood philosophy as the art of life and life as philosophical practice. Its practitioners sought to make decisions based on their own rationale so that they could freely shape their lives (Flachbartová, 2015, pp. 11-13). Although the works of the early Cynics have not been preserved, we have a rich doxographic and literary legacy that portrays their actions. In it, biographical elements are intertwined with fiction. However, these texts "are important for the understanding of the philosopher's stance. They also display an ethical message in practical situations" (Flachbartová, 2015, p. 30). "Cynic philosophical principles were absorbed into the Stoic tradition in the late-first and second centuries, and became largely indistinguishable from the Stoic agenda. As Christians absorbed Stoic models of thought, elements of Cynic thinking became part of Christian philosophy" (Krueger, 1993, pp. 29-30).

The ethical message hidden in the stories Gregory addresses to Nicobulo - as well as other readers - not only reveals his ideas about what makes a good life. It is a reminder that only those who really live a virtuous and ethical life can achieve it and that it is not enough to know about such a life. For it is $\pi \rho \tilde{\alpha} \xi l \varsigma$, not $\theta \varepsilon \omega \rho i \alpha$, that is but the sum of all virtues. $\Pi \rho \tilde{\alpha} \xi ı \varsigma$ leads to $\theta \varepsilon \omega \rho i \alpha$, i.e., spiritual knowledge that is the real knowledge (Špidlík, 2010, p. 189).

\footnotetext{
${ }^{47}$ PG 37, 696-698.

${ }^{48}$ PG 37, 700.

${ }^{49}$ PG 37, 705.

${ }^{50}$ Charés, Sententiae 2, 2-3.

${ }^{51}$ PG 37, 722.

52 PG 37, 723-724.

53 The legendary Attic figure Leos was said to have sacrified his three daughters - Praxithea, Theope and Eubule - in order to save Athens from plague and famine (Buol, 2018, p. 30).

${ }^{54}$ The son of Theban king Creon, who voluntarily sacrificed himself in the War of the seven against Thebes, when the city was in danger of being defeated.

55 Anaxarchos of Abdera was a Greek philosopher of the school of Democritus and was a contemporary of Alexander the Great.

${ }^{56}$ PG 37, 729-730.

${ }^{57}$ PG 37, 736-739.
} 
Practising the four virtues that Gregory of Nazianzus presents in the poem De virtute $(\mathrm{I}, \mathrm{II}, 10)$, should inspire people to lead a good life. Poverty offers him freedom, temperance guides him on the path of good deeds, courage helps him overcome fear - the strongest weapon of Evil -, and morality, closely related to prudence and wisdom, helps him approach God. It is precisely the knowledge of God, that is for Gregory the purpose of every endeavor $(\mathrm{I}, \mathrm{II}, 10,931) .{ }^{58}$ However, only knowing God is not enough. It is necessary to love, because love is a hospitable friend of knowledge $(\mathrm{I}, \mathrm{II}, 10,984)^{59}$ and those who do not love God cannot grasp Him (I,II, 25,363). ${ }^{60}$

One of the main features of the moral poetry of Gregory of Nazianzus is not only the return to older philosophical schools, but also the use of their means of expression. He uses practical examples of respectable behavior, called chreiai (Crimi, 1995, p. 41), in which the emphasis is on usefulness (Flachbartová, 2015, p. 31). These maxims held a specific place in cynicism and we can find them in Gregory's poetry, where they are used mainly as a means of enlivening interpretation but didactic significance is undeniable too (Crimi, 1995, pp. 41-42). Moreover, Gregory of Naziazus often uses the form of the so-called diatribe ${ }^{61}$ which was originally a witty satirical sermon preached by wandering philosophers, and turned later into critical or even shaming writings. Diatribe was often used by cynics and stoics, and some of Gregory's moral poems (or parts of them) can be considered diatribes, of which De virtute (I,II,10) and Adversus iram $(\mathrm{I}, \mathrm{II}, 25)$ are two examples.

Gregory of Nazianzus sought to influence young Christians by his poetry. He explained not only moral, but also dogmatic, autobiographical and lyrical themes with the explicit intention of advancing Christian ideology, while the poetic form was chosen deliberately as a more pleasant and attractive means of delivering the message. Moreover, Gregory sought to write Christian poetry that could rival and be an alternative to the appealing Hellenistic poetry. The quality of Gregory's poems disproved the contemporaneous polemical view that Christians lacked education and literary works (Drobner, 2011, p. 381). Gregory viewed Ancient scholarship (philosophy, literature, but also mythology) as a foundation upon which young Christians could rely under condition that they think critically and choose only the good and useful parts. He himself adopted an attitude of controlled acceptance of pagan teachings. $\mathrm{He}$ embraced what is good, but did not forget or constantly remind himself that above all is Love, Scripture (Logos in the fullest of its meaning), God. Gregory's poem I,II, $40^{62}$ De rerum humanarum vanitate expresses this attitude in its entirety. Since the poem concludes the moral poetry in the collection $P G$, it can be seen as a final reminder of the inevitability of death, for it is then that people face God's judgment. The ending also implies the importance of practising virtues on the way to knowing God:

Those who mimic spider fibers and rejoice in the delicacies in life let them know how easy the wind will dispose all that the spider finds pleasing.

You, whose thrones are beautifully decorated, who are proud of the prestige that is anyway ephemeral, beware of the final judgment that nothing can escape.

\footnotetext{
${ }^{58}$ PG 37, 747.

${ }^{59} \mathrm{PG} 37,751$.

${ }^{60} \mathrm{PG} 37,838$

${ }^{61}$ Diatribe typically contain elements of dialogue, rhetoric questions, shortened expressions, exclamations, imperative mood, comparisons, the use of gnomes, examples, etc.

${ }^{62}$ PG 37, 968.
} 
Philosophy is, in the work of Gregory of Nazianzus and in his overall attitude to life, one of the instruments, but not the ultimate goal of human existence. Despite its significance, it remains a mere instrument that sets the boundaries and leads to an understanding of the virtues and their meaning.

Translated by Ján Drengubiak

This article is a part of the results of grant VEGA 1/0114/17 Poemata moralia of Gregory of Nazianzus.

\section{References}

ARISTOTLE (2004): The Nicomachean Ethics. London: Penguin Books.

ARISTOTLE (1987): De Anima (On the Soul). London: Penguin Books.

BRISSON, L. (1993): Présupposés et conséquences d'une interprétation ésotériste de Platon. In: Les Études philosophiques, 4, pp. 475-495.

BRODŇANSKÁ, E. (2008): Cnosti očami Gregora Nazianzského a dnešnej doby [Virtues as seen by Gregory of Nazianzus and contemporary world]. In: H. Panczová (ed.): Patristická literatúra a európska kultúra [Patristic literature and European culture]. Trnava: Dobrá kniha, pp. 107-121.

BRODŇANSKÁ, E. (2017): Sv. Gregor z Nazianzu. Môj život (II,I,11) [St. Gregory of Nazianzus: My life (II,I,11)]. Trnava: Dobrá kniha.

BUOL, J. (2018): Martyred for the Church: Memorializations of the Effective Deaths of Bishop Martyrs in the Second Century CE. Tübingen: Mohr Siebeck.

CRIMI, C. (1995): Gregorio Nazianzeno. Sulla virtù carme giambico [I,2,10]. Pisa: Edizioni ETS.

DEMOEN, K. (1993): The attitude towards Greek poetry in the verse of Gregory Nazianzen. In: J. den Boeft \& A. Hilhorst (eds.): Early Christian poetry: A collection of essays. Leiden, New York \& Köln: Brill.

DROBNER, H. R. (2011): Patrologie: Úvod do studia starokřestanské literatury [Patrology: Introduction into early Christian literature]. Praha: OIKOYMENH.

FLACHBARTOVÁ, L. (2015): Diogenovský kynizmus ako spôsob života [Diogenes' Cynicism as way of life]. Prešov: Filozofická fakulta Prešovskej univerzity.

HADOT, P. (2004): What is ancient philosophy? Cambridge, MA: Harvard University Press.

KRUEGER, D. (1993): Diogenes the Cynic among the fourth century Fathers. In: Vigiliae Christianae, 47(1), pp. 29-49.

OBERHAUS, M. (1991): Gregor von Nazianz. Gegen den Zorn (Carmen 1,2,25). Einleitung und Kommentar. Paderborn, München, Wien \& Zürich: Ferdinand Schöningh.

OKÁL, M. (ed.) (1983): Zlomky starých stoikov [Fragments of the Old Stoics], transl. M. Okál. Bratislava: Pravda.

PANCZOVÁ, H. (2012): Grécko-slovenský slovník. Od Homéra po krestanských autorov [Greek-Slovak thesaurus: Since Homer to early Christian authors]. Bratislava: Lingea.

Patrologiae cursus completus. Series Graeca (1857-1858). Accurante J. P. Migne. Paris.

Plato (1961): The Collected Dialogues of Plato. New Jersey: Princeton University Press.

PLUTARCH (1936): The E at Delphi. In: Moralia, vol. V. Cambridge, MA: Harvard University Press.

PLUTARCH (2001): Plutarch's Lives. New York: Random House.

STÖRIG, H. J. (1985): Kleine Weltgeschichte der Philosophie. Stuttgart: Verlag W. Kohlhammer.

ŠPIDLÍK, T. (2010): Řehoř Naziánský. Úvod ke studiu jeho duchovní nauky [Gregory of Nazianzus: Introduction into the study of his spiritual teachings]. Olomouc: Refugium.

WHITE, C. (1996): Gregory of Nazianzus: Autobiographical poems. Cambridge: University Press. 